\title{
Implications of Philately in Promoting the Protected Natural Areas (IV): Domogled - Cerna Valley National Park
}

\author{
Bogdan-Vasile Cioruța ${ }^{1,2^{\star}}$, Alexandru Leonard Pop ${ }^{1}$ and Mirela Coman ${ }^{3,4}$ \\ ${ }^{1}$ Technical University of Cluj-Napoca - North University Centre of Baia Mare, Office of Informatics, \\ $62 A$ Victor Babeș street, 430083, Baia Mare, Romania. \\ ${ }^{2}$ Politehnica University of Bucharest, Faculty of Applied Sciences from Bucharest, \\ 313 Splaiul Independenței, 060042, Bucharest, Romania. \\ ${ }^{3}$ Technical University of Cluj-Napoca, North University Centre of Baia Mare, Faculty of Engineering, \\ 62A Victor Babeș street, 430083, Baia Mare, Romania. \\ ${ }^{4}$ University of Agricultural Sciences and Veterinary Medicine from Cluj-Napoca, Faculty of Agriculture, \\ 3-5 Calea Mănăştur, 400372, Cluj-Napoca, Romania.
}

\begin{abstract}
Authors' contributions
This work was carried out in collaboration among all authors. Authors BVC and ALP designed the study, performed the literature searches and wrote the first draft of the manuscript. Author MC managed the analyses of the study. All authors read and approved the final manuscript.
\end{abstract}

Article Information

DOI: $10.9734 / A J G R / 2020 / v 3 i 430120$

Editor(s):

(1) Dr. Xu Chong, China Earthquake Administration, China.

(2) Dr. Huan Yu, Chengdu University of Technology, China.

Reviewers:

(1) Rasajit Kumar Bera, National Institute of Technical Teachers' Training \& Research, India. (2) Nabanita Khuntia, Pondicherry University, India. (3) Seyed Daryoush Moghadds, Shahid Beheshti University, Iran. (4) Carolina Pinto Qmul, Queen Mary University of London, UK. Complete Peer review History: http://www.sdiarticle4.com/review-history/63117

Original Research Article

Received 02 October 2020 Accepted 09 December 2020 Published 21 December 2020

\section{ABSTRACT}

Romania is a blessed place with many areas of unique beauty, and with the most interesting species of flora and fauna for research - as part of the natural heritage - with places where the spectacle of nature delights your eyes and take your breath with every step. Constantly promoting philatelic themes that use natural wealth and the beauty of our country as subjects, the administrative entity (with various names over time) responsible for issuing postage stamps performs a series of postage stamps in whose images are found rarities of flora and fauna, a miracle of nature. To show that 
protected natural areas have a special beauty, and to make them known to everyone, in this paper, we bring to the discussion the most significant philatelic peculiarities in the Domogled - Cerna Valley National Park. Also, through this paper, we tried to highlight the main post-philatelic effects (postage stamps, first-day covers - FDCs, illustrated postcards, maximum postcards, occasional envelopes, and other postal circulations), which appeared at the level of Romanian thematic philately, concerning the studied area. Through their prism, we tried to show that besides the role of ambassador of beauties and national heritage, the thematic philately has implications in the protection of species of flora and fauna. About other areas of interest, where the philatelic products were not highlighted, it can be mentioned that in the considered area (Domogled - Cerna Valley National Park) the management of the protected area only had to gain.

Keywords: Biodiversity; Domogled - Cerna Valley National Park; natural heritage; philately.

\section{INTRODUCTION}

Domogled - Cerna Valley is a protected area of national interest that corresponds to the second category IUCN (national park), located in the southwestern part of Romania, on the territories of Caraş-Severin, Mehedinți and Gorj counties $[1,2]$.

The natural area is located in the central-eastern part of Caraş-Severin county (on the administrative territories of Cornereva, Mehadia, Teregova, Topleţ and Zăvoi communes and of Băile Herculane city), the north-western part of Gorj county (on Padeş commune and Tismana city) and in the northeast of Mehedinţi County (on

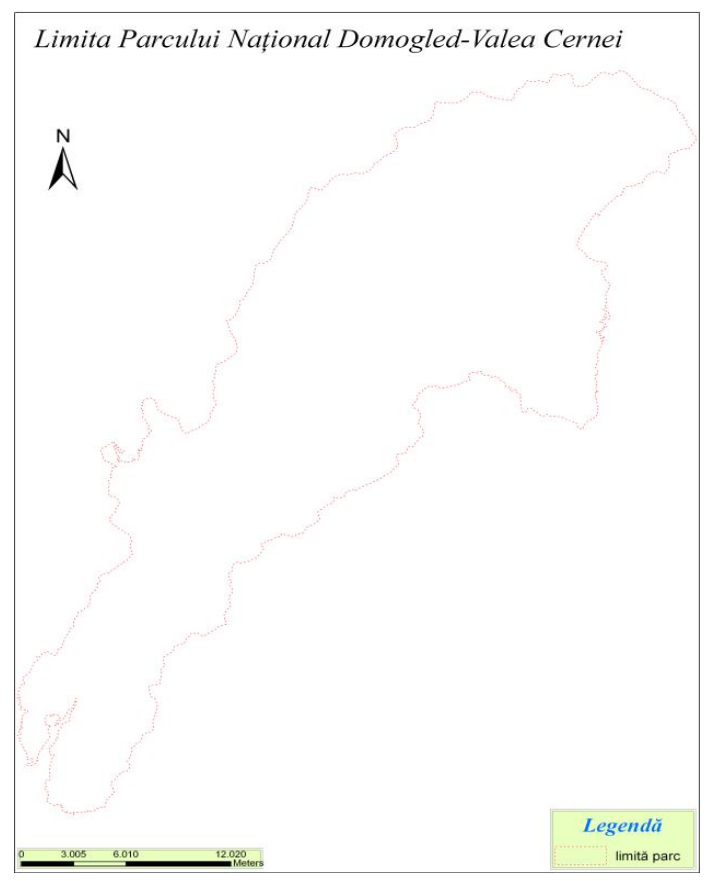

the territories of Balta, Isverna, Obârşia-Cloşani and Podeni communes) and is to be crossed by the national road $66 \mathrm{~A}$, to connect Hunedoara and Caraş Severin counties. From the point of view of geo-positioning, the area is between the coordinates $45^{\circ} 05^{\prime} 35^{\prime \prime}$ lat. $\mathrm{N}$ and $22^{\circ} 37^{\prime} 27^{\prime \prime}$ long. $\mathrm{E}$, and $45^{\circ} 09^{\prime} 306^{\prime \prime}$ lat. $\mathrm{N}$ and $22^{\circ} 62^{\prime} 417^{\prime \prime}$ long. $\mathrm{E}$, as it can be observed, at the schematic level, in Fig. 1 [2-4].

The park is a mountainous area with a great geological and geomorphological diversity (karst relief with sharp peaks, towers, needles, limestone ridges, caves, quays, valleys, forests, and meadows), which has several types of habitats $[1,3]$.

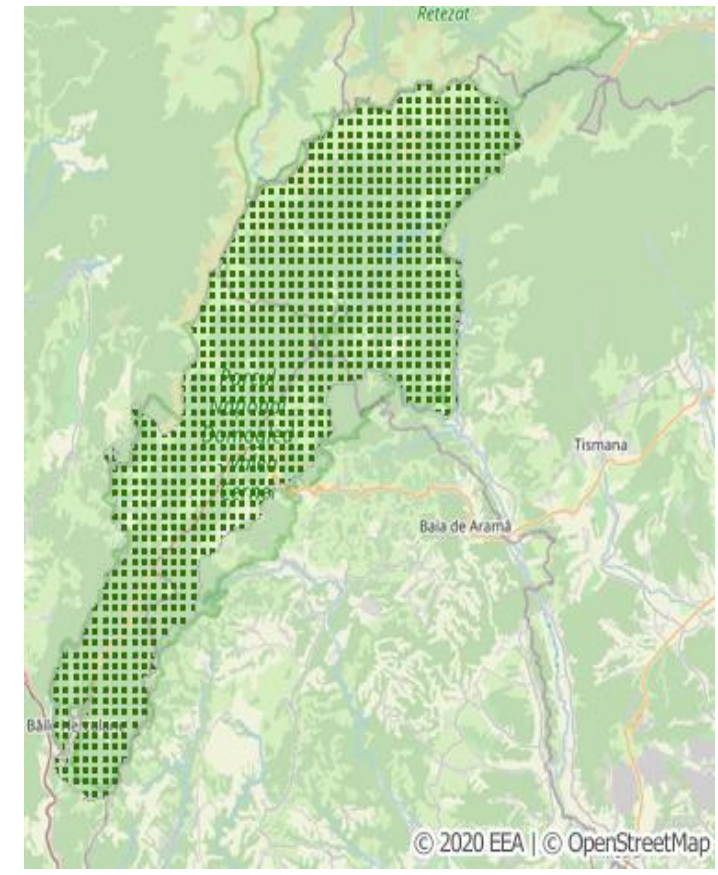

Fig. 1. Reference area of Domogled - Cerna Valley National Park (Romania) $[2,3]$ 
The first proposal for the establishment of the Domogled - Cerna Valley National Park took place in 1990, and it will be declared a protected area by Law no. 5 of March 6, 2000 (on the approval of the National Spatial Planning Plan Section III - protected areas) [5]. In 2003, by Government Decision no. 230 of 4 March [6] (on the delimitation of biosphere reserves, national parks, and natural parks and the establishment of their administrations) restores its boundaries and area.

From a geographical point of view, the park stretches over the Cerna river basin, from its source to the confluence with the Belareca river, over the massif of Godeanu Mountains and Cerna Mountains on the right slope, respectively Vâlcanului and Mehedinţi Mountains on the left slope. The surface of the Domogled - Cerna Valley National Park is of 61,211 ha and is comprised between the northern latitudes of $44^{\circ}$ 50 '10 "and 45 $15^{\circ}$ ' 50", and the eastern longitudinal latitudes of $22^{\circ} 23$ '50 "and $22^{\circ} 51^{\prime}$ 35". Domogled - Cerna Valley National Park is located in the east of Caraş-Severin county, occupying an area of 23,185 ha, in the west of Mehedinţi county occupying an area of 8,220 ha, and in the west of Gorj county with an area of 29,806 ha.

\section{MATERIALS AND METHODS}

The documentation for this paper started from the authors' concerns for environmental education and environmental protection $[7,8]$, and not least, because they love the idea of a harmoniously developed community, with care for protected areas and the biodiversity that populates them $[9,10]$. Having at hand a series of extremely relevant studies at the national level, both in terms of the management of protected areas [11-13] and the philatelic issues published in catalogues and journals [14,15], the authors decided to extrapolate those approaches to the relatively limited space of the existing ecosystem in Domogled - Cerna Valley National Park. The subject of the study, in the form of a philatelic circuit of Domogled - Cerna Valley National Park, is based on the sites that host philatelic content (such as Colnect, Delcampe, eBay, PicClick, Okazii, StampWorld, wopa-plus, etc.), which come in addition to discussion forums and online meetings with other collectors and passionate philatelists. They were kind enough not only to clarify some purely philatelic aspects to us, where the consulted literature left room for interpretations, but, in some cases, they also made available study materials, including pieces from their collections.

\section{RESULTS AND DISCUSSION}

\subsection{Domogled - Cerna Valley National Park from an Ecological Perspective}

Domogled - Cerna Valley National Park is a mountainous area (with rocks, limestone cliffs, peaks, sinkholes, lapis lazuli, caves, oats, rubble, gorges, waterfalls, meadows, and forests) in the area which includes the Coronini - Bedina nature reserves, Domogled Reservation, lardașița, launa - Craiova, Bârzoni Cave, Corcoaiei Gorges, Ciucevele Cernei, Cloșanilor's Stone, Stan's Peak and Țesna Valley [1,2].

The natural area has several types of habitats beech forests of Symphyto-Fagion, AsperuloFagetum and Cephalanthero-Fagion, alluvial forests with Alnus glutinosa and Fraxinus excelsior, acidophilous forests of Picea abies in the mountain region, acion forests on steep slopes, alpine and boreal scrub, alpine and subalpine calcareous meadows, Pannonian rocky meadows, calcareous scrub meadows, edging communities with high hygrophilous grasses from the plains to the mountainous and alpine to the siliceous mountain in the alpine, mountain meadows, caves where public access is forbidden, rocky slopes with chasmophytic vegetation on limestone rocks, subMediterranean forest vegetation that shelter a diverse range of flora and fauna specific to the Carpathian chain of the Retezat-Godeanu Mountains [1,2].

The national park overlaps both the site of Domogled - Cerna Valley community importance area and the special protection avifauna area of the same name $[3,4]$, based on the designation of several faunal and floristic species listed in European Council Directive 92/43/EC of 21 May 1992 (on the conservation of natural habitats and of wild fauna and flora). The protected fauna of the park consists of $[1,2]$ :

- 14 species of mammals: brown bear (Ursus arctos), gray wolf (Canis lupus), lynx (Lynx lynx), river otter (Lutra lutra), long-winged bat (Miniopterus schreibersi), large horseshoe bat (Rhinolophus ferrumequinum), the brick bat (Myotis emarginatus), the big-eared bat (Myotis bechsteini), the horseshoe bat of Blasius (Rhinolophus blasii), the Mediterranean bat (Rhinolophus euryale), the small 
horseshoe bat (Rhinolophus hipposideros), the bat with mouse ears (Myotis blythii) and the bat with long legs (Myotis capaccinii);

- a reptile and an amphibian: the land tortoise (Testudo hermanni) and the yellow-bellied ivory (Bombina variegata);

- six species of fish: the ford pig (Gobio uranoscopus), the woodpecker (Cottus gobio), the stingray (Sabanejewia aurata), the avat (Aspius aspius), the eggplant (Barbus meridionalis) and the squid (Eudontomyzon danfordi);

- 22 species of invertebrates, among which we mention the short-winged beetle (Oxyporus mannerheimii), the golden beetle (Buprestis splendens), the beetle (Carabus variolosus), the Transylvanian moth (Pholidoptera transsylvanica), the beetle (Lucanus cervus), the large tailor of the oak (Cerambyx cerdo), the alpine tailor (Rosalia alpina), etc.

At the level of grasses, there are three species of plants [1,2]: the lady's slipper (Cypripedium calceolus), the poplar eggs (Himantoglossum caprinum) and the mountain bell (Campanula serrata), which vegetates along with other floristic rarities, among which: bear's foot (Acanthus longifolius), sea-grass (Achnatherum calamagrostis), Boiler bells (Campanula crassipes), strawberry (Cephalanthera damasonium), mountain carnation (Dianthus pestal), motley tulip (Fritillaria orientalis), forest lily (Linum uninerve), etc.

\subsection{Domogled - Cerna Valley National Park from a Philatelic Perspective}

From a postal-philatelic point of view, the research undertaken on the main e-commerce sites with philatelic content (Colnect, Delcampe, PicClick, Stamp World, wopa-plus, etc.) led us to identify the pieces reproduced in Fig. 2 [16] and Fig. 3a-e [17-21].

Romfilatelia, a permanent promoter of philatelic themes that have as subject the undisputed beauties of Romania, introduced into circulation the issue of postage stamps "Natural Parks of Romania", stopping for the moment in the Domogled - Cerna Valley National Park [22,23].

On the stamp of the lacy package of the issue with a face value of 28.50 lei (see Fig. 4), is shown Zamenis longissimus, also called the Aesculapian Snake, which, wrapped on a stick, is the symbol of medicine [22]. Aesculapian snake is a non-venomous snake in the family Colubridae. The length of this specimen can reach up to $2 \mathrm{~m}$. It has a slender appearance, small and narrow head, long and thin tail. The back is brown with many scales, long with white stripes. When caught, it quickly gets angry and bites, hence being called in some areas "bad snake".

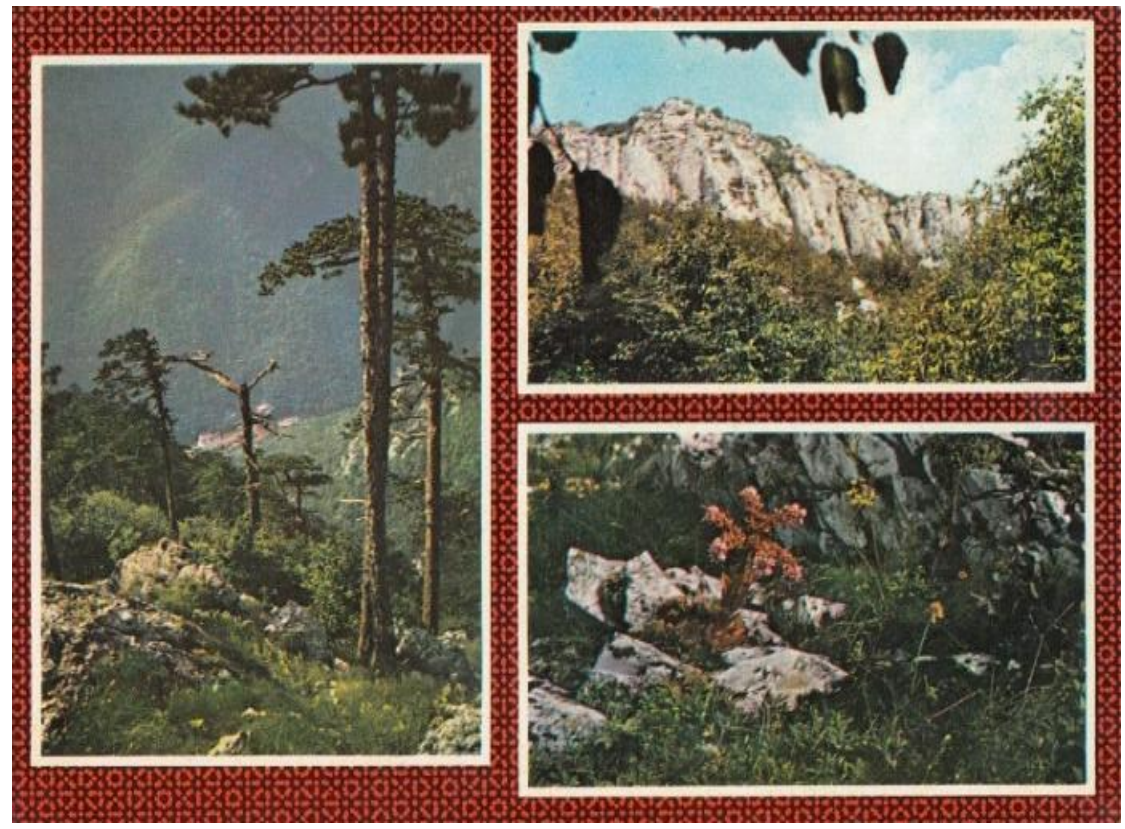

Fig. 2. Illustrated postcard "Băile Herculane. Domogled Nature Reserve" 




(a) "Cerna Valley"



(b) "Valea Cerna at Băile Herculane"

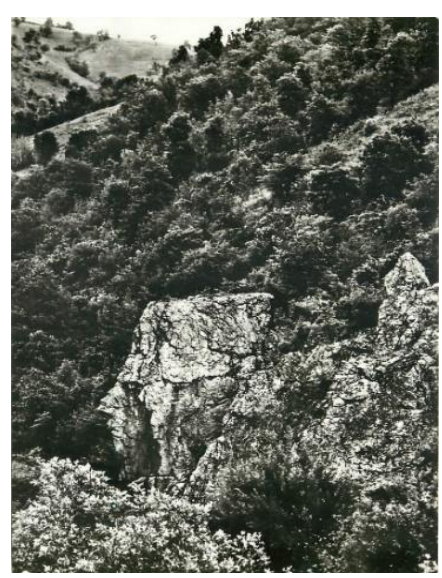

(c) "The Banat Sphinx from the Cerna Valley"

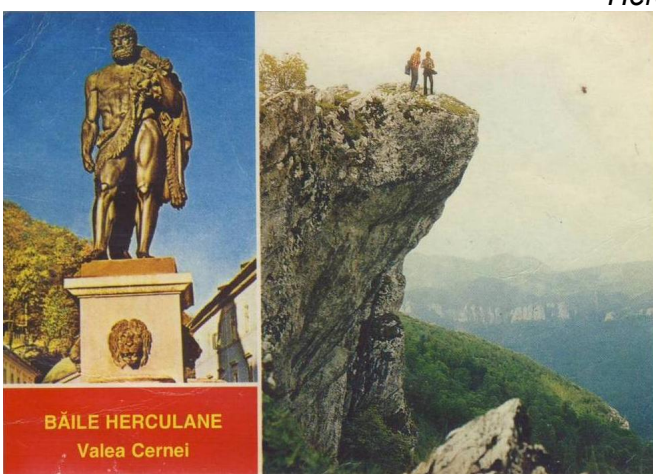

(d) "Herculane baths. Cerna Valley"

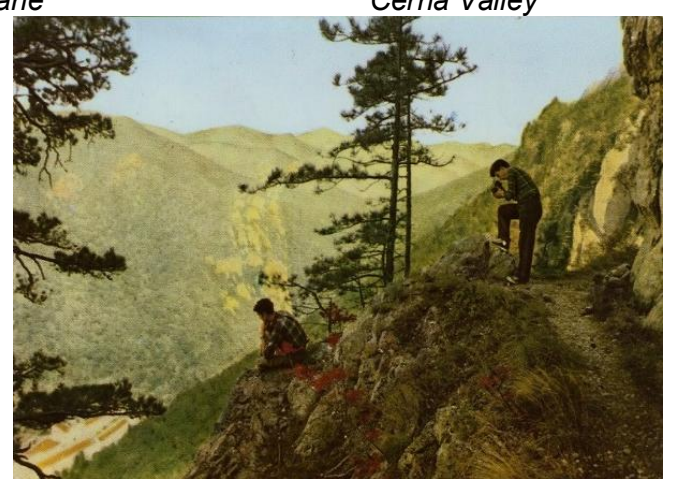

(e) "Cerna Valley"

Fig. 3. Illustrated postcards referring to the Domogled - Cerna Valley area

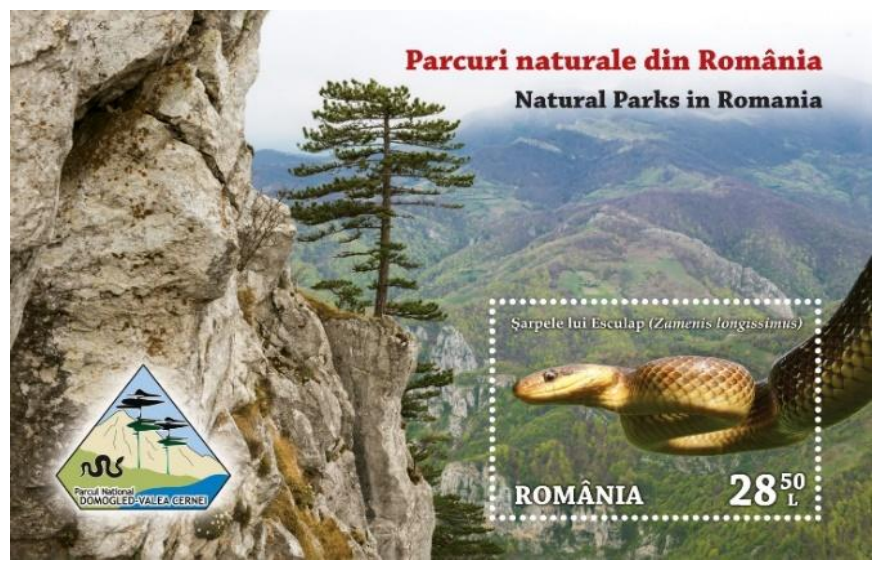

Fig. 4. The souvenir sheet of the "Natural Parks in Romania", 17.08.2018, Bucharest

The issue of postage stamps is completed by the set of two FDCs - first-day covers (see Fig. 5), the set of four maximum postcards (see Fig. 6), and as layout forms were used the sheet of 32 stamps, the mini-sheet of 5 stamps +1 vignette, and the block of 4 stamps in the philatelic album (see Fig. 7) [22,23].
The philatelic album is made in a limited edition of 245 copies and is equipped with the special block of the issue (containing four lacy stamps with illustrated cuff), as well as the envelope "first day" with the stamp "first day" clearly applied with folio, both products being numbered from 001 to 245 . 

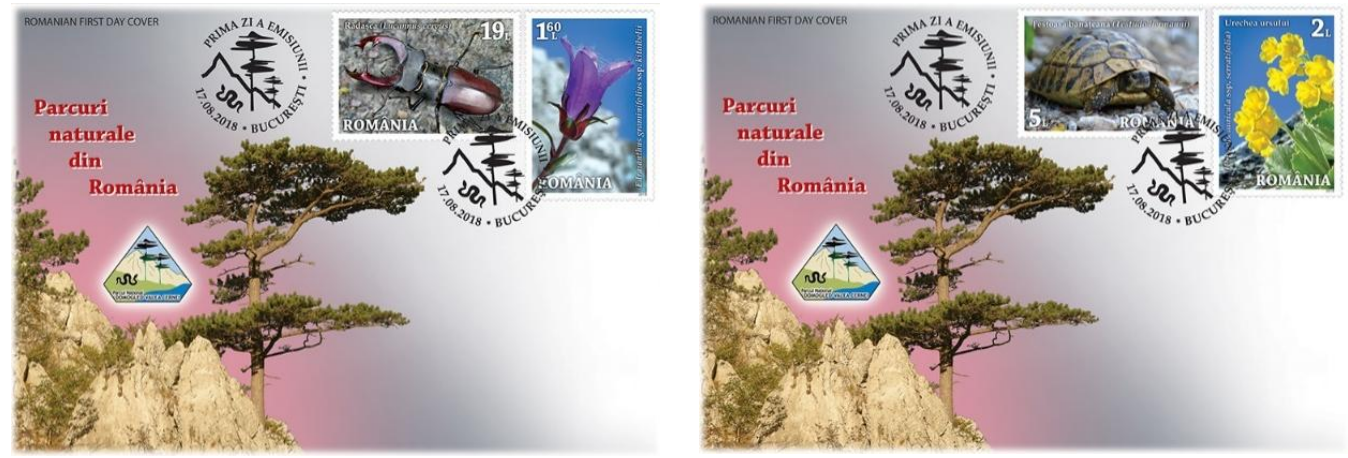

Fig. 5. The FDCs of the "Natural Parks in Romania", 17.08.2018, Bucharest

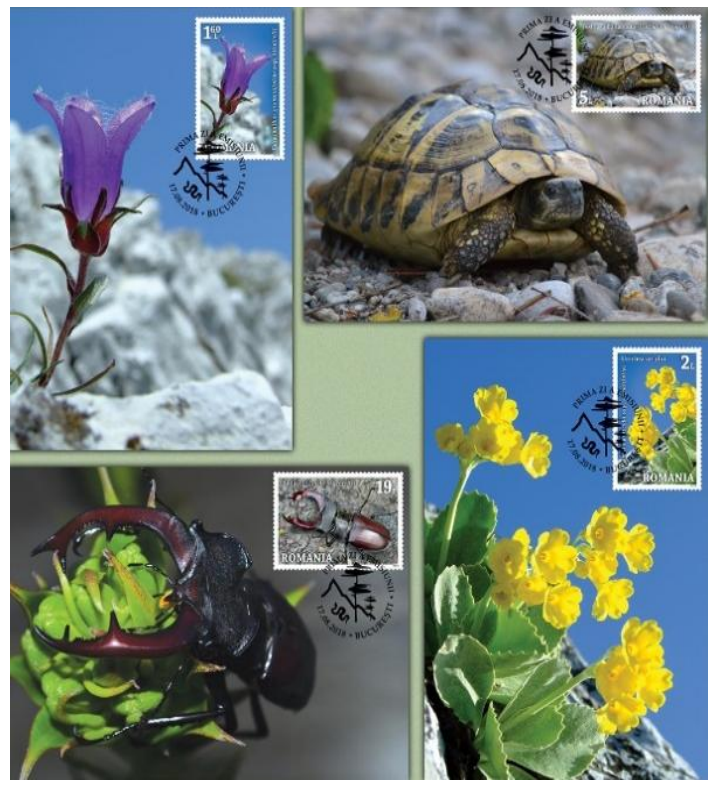

Fig. 6. The maxicards of the "Natural Parks in Romania", 17.08.2018, Bucharest

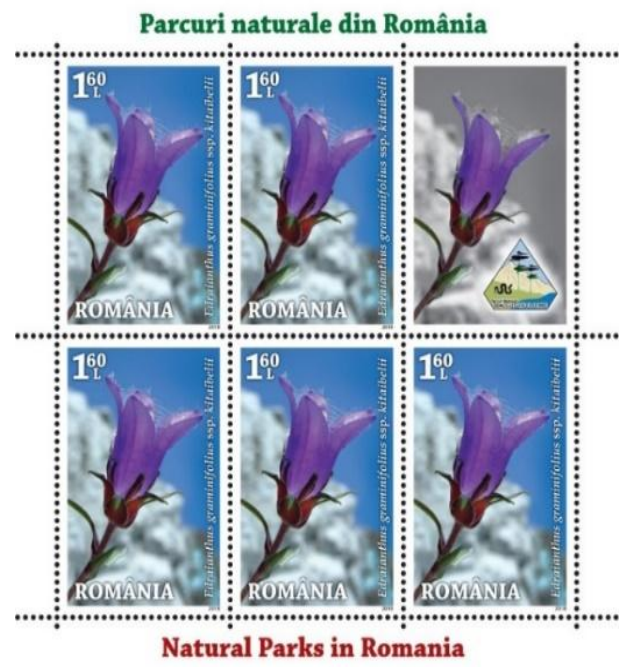

(a) Edraianthus graminifolius ssp. kitaibelii

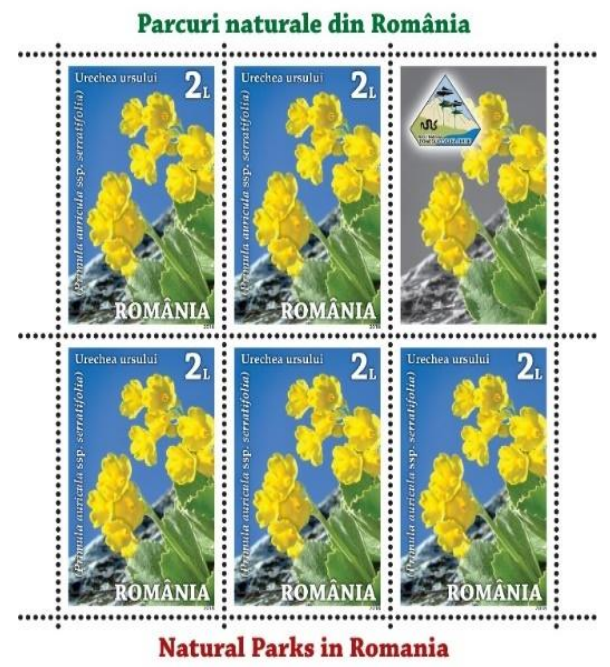

(b) Primula auricula ssp. Serratifolia 


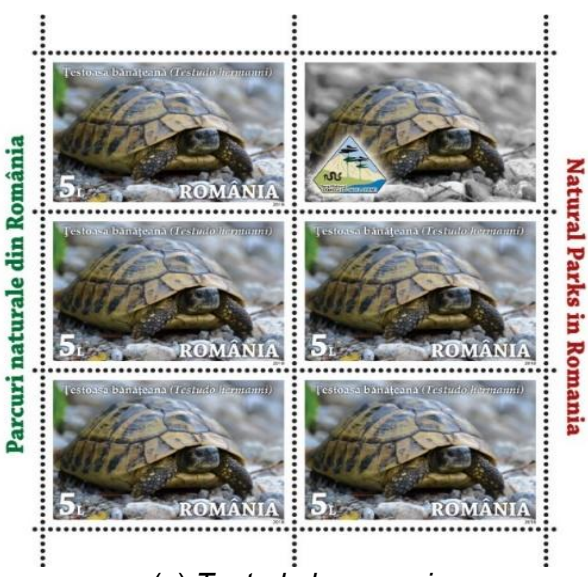

(c) Testudo hermanni

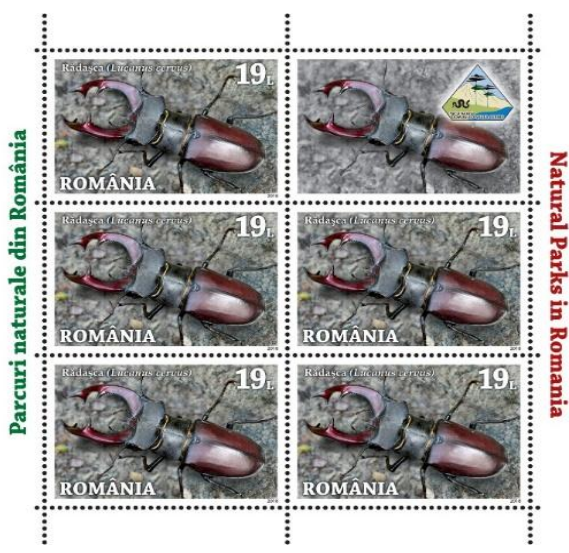

(d) Lucanus cervus

Fig. 7. The 4-stamps blocks of the "Natural Parks in Romania", 17.08.2018, Bucharest

Edraianthus graminifolius ssp. kitaibelii (Fig. 7a) is a xero-mesophilic species, which grows as a perennial herbaceous plant. The plants are low and their stems can be from $1 \mathrm{~cm}$ to a maximum of $20 \mathrm{~cm}$ [22]. The leaves are alternately arranged on the stem, and the lower ones are mainly petiolate. The blue-purple flowers are individually grouped, bell-shaped and hermaphroditic. Due to the small area in which it can be found, this species is protected.

Primula auricula ssp. Serratifolia (Fig. 7b) also called the Banat Cuckoo's Cube or the Bear's Ear, it is among the species with the highest phytogeographic value in the Primulaceae family, representing an endangered taxon [22]. It usually blooms from April to the end of May. It is a perennial species that grows up to $20 \mathrm{~cm}$ in height. Yellow flowers grow in clusters on stems $5-20 \mathrm{~cm}$ long. The specific epithet auricle means "ear-shaped" and refers to the shape of the leaves.

Testudo hermanni (Fig. 7c) belongs to the Testudinae family and is characterized by the carapace of $12-24 \mathrm{~cm}$, which is convex, yellowbrown with dark spots [22]. A tortoise can easily reach $25-30 \mathrm{~cm}$ in diameter at maturity and $2-3$ $\mathrm{kg}$ in weight. In optimal living conditions they can live even over 75 years.

Lucanus cervus (Fig. 7d), known as the radish, it is a beetle in the Lucanidae family. Is also one of the largest and most remarkable beetles in Europe [22]. Characteristic are the large, reddish mandibles of the male, which resemble deer antlers and can be moved like pliers. In large specimens, the length of the horns can reach almost half of the total length of the beetle, which is $25-75 \mathrm{~mm}$.
Regarding the technical characteristics of the "Natural Parks in Romania", they have been summarized in Table 1, and refer to stamps, as well as the block and souvenir sheet [22,23]. The philatelic album is created into a limited edition (only 245 pieces) and is equiped with the special bloc of the issue, as well as the FDCs.

As it has been shown so far, regarding the implications of the Romanian thematic philately in the promotion of the considered area, these are as obvious as possible. The richness of the post-philatelic material (postage stamps, first-day covers - FDCs, illustrated postcards, maximum postcards, occasional envelopes, and other postal circulations), which was, in turn, identified, indexed and analyzed, helped, over time, to promote the elements of interest in the area. Thus, those who chose to cross the threshold of the protected area (mainly tourists coming from abroad), saw the beauty of the postal materials translated into reality.

Moreover, through thematic philately, they already had a wealth of knowledge relative to the area. Although there is no clearly defined statistic in this regard, Domogled National Park - Valea Cernei thus managed to attract more tourists, and thus achieve its objectives due to the implications of philately compared to other protected areas where the implications of philately were ignored. How effective were the implications of philately in Domogled - Cerna Valley National Park in public awareness and the attraction of ecotourism? The answer is still a vague one. However, no implications have yet been reported on the behavior of tourists as a result of promoting the area through philately. 
Table 1. Technical characteristics for stamps of the "Natural Parks in Romania", 17.08.2018, Bucharest

\begin{tabular}{ll}
\hline Technical characteristics & Values and other observations \\
\hline Date of issue & 17.08 .2018 \\
\hline Number of values & $5(4$ stamps +1 perforated souvenir sheet) \\
\hline Stamp/Block/Minisheet size & $33 \times 48 \mathrm{~mm} / 112 \times 152 \mathrm{~mm} / 115 \times 118 \mathrm{~mm}$ \\
\hline Page composition & $\begin{array}{l}\text { In sheet of } 32 \text { stamps, minisheet of } 5 \text { stamps + } 1 \text { label with } \\
\text { illustrated border and block of } 4 \text { imperforated stamps }\end{array}$ \\
\hline Printing system & Offset, in 4 colours on chromo-gummed paper - UK origin \\
Run printing & 68,280 stamps $-38,400$ in sheets of 32 stamps, 24,600 in \\
& minisheets of 5 stamps + 1 label with illustrated border $(4,920$ \\
& minisheets) and 980 in blocks of 4 imperforated stamps (245 \\
& blocks) and 4,300 in perforated souvenir sheets \\
\hline Designer & Mihai Vămășescu \\
\hline FDC & $\begin{array}{l}470 \text { sets }(2 \text { covers) equipped with the postage stamps of the } \\
\text { issue, numbered and cancelled with the ,first day” postmark }\end{array}$ \\
\hline Listing & 2207(set), 2207a (perforated souvenir sheet), and 2207b \\
& (philatelic album) \\
\hline
\end{tabular}

\section{CONCLUSION}

In the paper, we bring to the fore the area of Domogled - Cerna Valley National Park both from an ecological point of view - by presenting the species of flora and fauna in the form of a short inventory, and philatelic point of view - by analyzing, describing and disseminating the main pieces identified in within philatelic content ecommerce sites. We were impressed by the way in which over time the Romanian postal administration via Romfilatelia decided to promote protected natural areas, the pieces identified being of a rare beauty, especially those made in 2018, as part of the philatelic project "Natural Parks in Romania".

As a result of our research, it should be emphasized that where the implications of philately are visible (especially through the richness of the postal-philatelic material), a good policy is often outlined in terms of promoting the intrinsic values of the area. In this way, we consider it opportune to involve philately as an ambassador for the promotion of protected areas, especially where the management of these areas is deficient; the visibility of the area's heritage via thematic philately can be a good landmark in rethinking community development strategies in terms of ecosystem services.

\section{COMPETING INTERESTS}

Authors have declared that no competing interests exist.

\section{REFERENCES}

1. Available:https://ro.wikipedia.org/wiki/Parc ul_Național_Domogled_-_Valea_Cernei

2. Available: $\bar{w} w w$.domogle $\bar{d}-\mathrm{cerna}$.ro

3. Available:https://eunis.eea.europa.eu/sites/ 11175

4. Available:www.protectedplanet.net/parculnational-domogled-valea-cernei

5. LAW no. 5/2000 on the approval of the National Spatial Planning Plan - Section III - protected areas, Romanian.

Available:www.cdep.ro/pls/legis/legis_pck. htp_act_text?idt=22636.

6. DECISION no. 230 on the delimitation of biosphere reserves, national parks and natural parks and the establishment of their administrations; 2003.

Available: www.legex.ro/Hotararea-2302003-36800.aspx. Romanian.

7. Pop AL, Cioruța B, Coman M, Considerations regarding the implications of philately in ecological education, Scientific Bulletin of North University Center of Baia Mare, Mining, Mineral Processing, Non-ferrous Metallurgy, Geology \& Environmental Engineering. Baia Mare. 2017;31(1):57-62.

8. Mesaroș M, Cioruța $B$, Coman $M$, Protected natural heritage on route from philosophy to environment engineering, Scientific Bulletin of North University Center of Baia Mare, Mining, Mineral Processing, Non-ferrous Metallurgy, Geology \& Environmental Engineering. Baia Mare. 2018;32(1):63-72. 
9. Cioruța B, Pop AL, Coman M, Lauran A, Implications of philately in promoting the protected natural areas (I): Ceahlău national park, scientific bulletin of north university center of baia mare, series d, mining, mineral processing, nonferrous metallurgy, Geology and Environmental Engineering, Baia Mare. 2018;32(1):87-96.

10. Pop AL, Cioruța B, Coman M, Implications of philately in promoting the protected natural areas (II): pețea creek natural reservation, scientific bulletin of North University Center of Baia Mare, series d, mining, mineral processing, non-ferrous metallurgy, Geology and Environmental Engineering, Baia Mare. 2018;32(2):43-52.

11. Stanciu E, Florescu F. Protected areas in Romania, green steps publishing house, Braşov, Romanian; 2009.

Available:https://propark.ro/images/upload s/file/manual arii protejate_net.pdf.

12. Rațiu A. Legal regime of protected natural areas - practical aspects, Brașov; 2017. Available: www.juridice.ro/wpcontent/uploads/2016/11/Regimul-juridical-ANP-aspecte-practice_Antoanela.pdf. Romanian.

13. Government emergency ordinance no. $57 / 2007$ regarding the regime of protected natural areas, conservation of natural habitats, of wild flora and fauna, Official Gazette no. 442/2007.

Available:https://aliantasportnatura.wordpr ess.com/legea-ariilor-protejate
14. Tudor Gh, Chiricheş C, Mermeze Gh. Catalog of Romanian postage stamps 1990-2017 (LP \#1233-2135), Editura AXA, Bucureşti, Romanian; 2017.

15. Scăiceanu C. Catalog of layout designers of Romanian postage stamps, Oscar Print Publishing House, Bucharest, Romanian; 2018.

16. Available:www.delcampe.net/en_US/collec tibles/postcards/romania/baile-hērculanerezervatia-naturala-domogled403912554.html

17. Available:www.delcampe.net/en_US/collec tibles/postcards/romania/roumanie-baileherculane-valea-cernei-csernatal-1925795827999.html

18. Available:www.delcampe.net/en_US/collec tibles/postcards/romania/valea-cernei1994-nice-stamp-airplane-tarom215004129.html

19. Available:www.delcampe.net/en_US/collec tibles/postcards/romania/d1226-sfinxulbanatean-valea-cernei-559118798.html

20. Available:www.delcampe.net/en_US/collec tibles/postcards/romania/valea-cernei1994-nice-stamp-airplane-tarom215004129.html

21. Available:www.delcampe.net/en_US/collec tibles/postcards/romania/valea-cernei383531885.html

22. Available:http://romfilatelia.ro/magazin/pro dus/colectii-anuale/parcuri-naturale-dinromania

23. Available:https://alexantonache.wordpress. com/page/3/?s=2019

(c) 2020 Cioruța et al.; This is an Open Access article distributed under the terms of the Creative Commons Attribution License (http://creativecommons.org/licenses/by/4.0), which permits unrestricted use, distribution, and reproduction in any medium, provided the original work is properly cited.

Peer-review history:

The peer review history for this paper can be accessed here: http://www.sdiarticle4.com/review-history/63117 